\title{
RISK IDENTIFICATION AS A BASIC STAGE OF THE PROJECT RISK MANAGEMENT
}

\author{
HANNA SOROKA-POTRZEBNA
}

University of Szczecin, POLAND

e-mail: hanna.soroka@wzieu.pl

\author{
RECEIVED \\ 20 April 2018 \\ ACCEPTED \\ 12 July 2018 \\ JEL \\ CLASSIFICATION \\ $\mathrm{D} 81, \mathrm{G} 32, \mathrm{O} 22$
}

KEYWORDS

risk, project, management, risk identification

ABSTRACT

The decision-making during realization of the project is connected with a relatively high risk. In practice, the risk is defined as the product of the probability of occurrence an event and the effects of its impact on the processes in the organization. Risk management is the essence of the functioning of every project.

The exact risk identification is crucial for the implementation of the project. Thanks to identification, organization can adopt an appropriate strategy to avoid the risk, minimize it, intensify its effects or simply eliminate it. In the literature, there are many definitions of risk in project, as well as descriptions of the stages of project risk management.

This article show the analysis of the literature on the subject to emphasize the importance of the risk identification as a basic stage of the project risk management. It also helps answer the question are enterprises are making a risk identification before implementation of their projects, and what type of risks they encounter.

\section{Introduction}

Risk management and risk identification play an important role in many areas of business activity of enterprises, especially during project implementation, which is due to several reasons. First of all, each project is unique, which means that it involve a significantly higher level of risk compared to other areas of the company's operations (Roszkowski, 2014, p. 155). Secondly, the lack of full knowledge of future periods is characteristic for projects, 
which is closely related to uncertainty and risk (Wyrozębski, 2014, p. 104). Thirdly, the implementation of projects usually requires significant investment costs. Consequences of making incorrect decisions resulting from the lack of risk identification in the project can be very harmful for the enterprise.

The aim of the article is to emphasize the importance of the risk identification process. To achieve this goal, the risk definitions were indicated with particular emphasis on the project risk, and also risk identification was presented as one of the stages of the risk management process. The empirical part of the article is the presentation of the results of the research on risk identification in projects implemented by entrepreneurs from the Western Pomerania.

\section{Literature review}

In the literature there are many definitions of risk. T.H. Bednarczyk defines it as the possibility of occurrence of negative socio-economic phenomena (Bednarczyk, 2000). T.T. Kaczmarek defines it as the possibility of failure, and in particular the occurrence of events beyond the control of the acting subject, which he can not accurately predict and which can not fully prevent, and which - by reducing the useful results and/or by increasing expenditures - receive action entirely or partly attribute effectiveness and economic viability (Kaczmarek, 2005). Other definitions define risk as:

- a combination of the probability of an event and its effects (ISO IEC Guide 73:2002),

- a probability, a mathematical quantity that can be measured, calculated or estimated (Hall, 2002),

- either a condition of, or a multi-dimensional measure of, exposure to unpredictable loss or losses (Yellman, 2000),

- an undesirable situation or circumstance that has both a likelihood of occurring and a potential negative consequence on the project (Space Project Management, 2000).

The concept of risk is also widespread in the field of project management. From the point of view of the risk occurring in projects, it is worth recalling the risk definition proposed in the standards of Project Management Institute (PMI). According to this institution, the risk is an uncertain event or circumstance which, if it occurs, may have a positive or negative impact on at least one of the project's objectives, such as scope, time, cost or quality (PMI, 2013, p. 309). Project risk is also defined as the probability of occurrence of a phenomenon or activity that may have positive or negative effects on the course of the whole project and/or its individual parts (Project Cycle Management Guidelines, 2004, p. 145).

In the article, project risk is understood negatively, that is, as a potential event or circumstance that may contribute to project delay, increase costs of its implementation or cause other unfavorable changes in the project (Tkaczyński, Świstak, Sztorc, 2011, p. 363).

Risk management is a process of undertaking risk-related activities by organization and achieving an acceptable level of that risk (Jajuga, 2007, p. 15). According to other definition, risk management mean identifying, measuring and controlling risks in order to limit as much as possible and protect against its consequences (Baker, 2000 , p. 23).

In the literature in the field of project management, risk management involves identifying specific threats to the project system and determining actions aimed to eliminate these risks or minimize the impact of them on the project (Zaskórski, Woźniak, Szwarc, Tomaszewski, 2013, p. 271). This activities should be implemented at all stages of the project life cycle: during the preparation of the project, its implementation and formal closure. The risk 
management process consists four basic stages: risk identification, risk analysis, risk control and risk monitoring. The risk management process does not end after the completion of all consecutive stages, but it should be carried out continuously and improved, using the knowledge and experience gained at earlier stages (Figure 1).

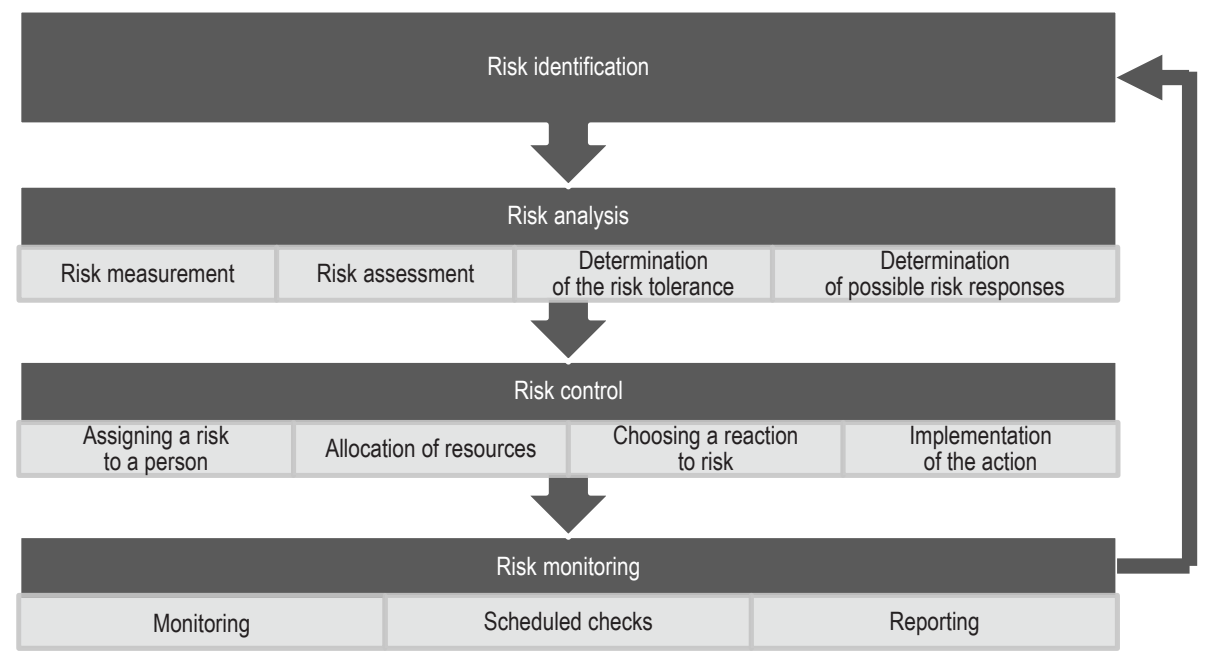

Figure 1. Process of the project risk management

Source: Szczepaniak (2013).

Four basic stages related to risk management are:

1. Risk identification - defining the risk to which the project is exposed as well as relations occurring between individual risks. It should be performed repeatedly during planning and during the implementation of the project.

2. Risk analysis qualitative and quantitative. Qualitative analysis of the risk management process based on estimating the probability and the effects of the occurrence of previously identified risks. At this stage of the process risk manager should prepare hierarchies of identified dangers according to their potential impact on the process of project implementation. The obtained results are used for further planning the reactions on unfavorable event. The quantitative analysis of the risk management process is aimed at determining quantifiable values of the probability value and the effects of unfavorable events both for individual project activities and for the entire undertaking. Quantitative risk analysis is often preceded by qualitative research (Skorupska, Kuchta, Górski, 2012, p. 61).

3. Risk control - planning activities aimed at minimizing the identified risk. In the process of planning risk responses are commonly used several strategies. For each of the risks, a plan of action should be selected so that the actions taken are as effective as possible. The most popular strategies include:

- avoiding the risk - modification of project implementation plans to eliminate a risk or a favorable change in the conditions related to it,

- risk transfer - transferring the effects of a risk to another entity, 
- risk mitigation - the most common of all risk response strategies, based on taking specific actions to reduce the likelihood or impact of risk,

- risk acceptance - accepting and bearing all consequences resulting from the possible occurrence of an unfavorable events,

- emergency plan - is built only for identified risks that may arise during the implementation of the project.

4. Risk monitoring - monitoring and controlling changing risk factors in the project (Wysocki, 2013, pp. 125-134).

The stage of risk identification is a very important, if not the most important stage of the risk management process. At this stage, there are recognition of as many uncertain events as possible that may affect the achievement of the intended goal of the project (Klinowski, 2014, p. 228). Based on the work carried out on the risk identification, a list of potential events with a description of the characteristics and warning signals about their occurrence is prepared (Roszkowski, 2013, p. 161).

The key issue during the recognizing of the risk is to gather information about risk factors. These are the causes (sources) of threats that can lead to negative consequences during the implementation of the project (Rytel, 2010, p. 161). The sources of the project threats are presented in Figure 2.

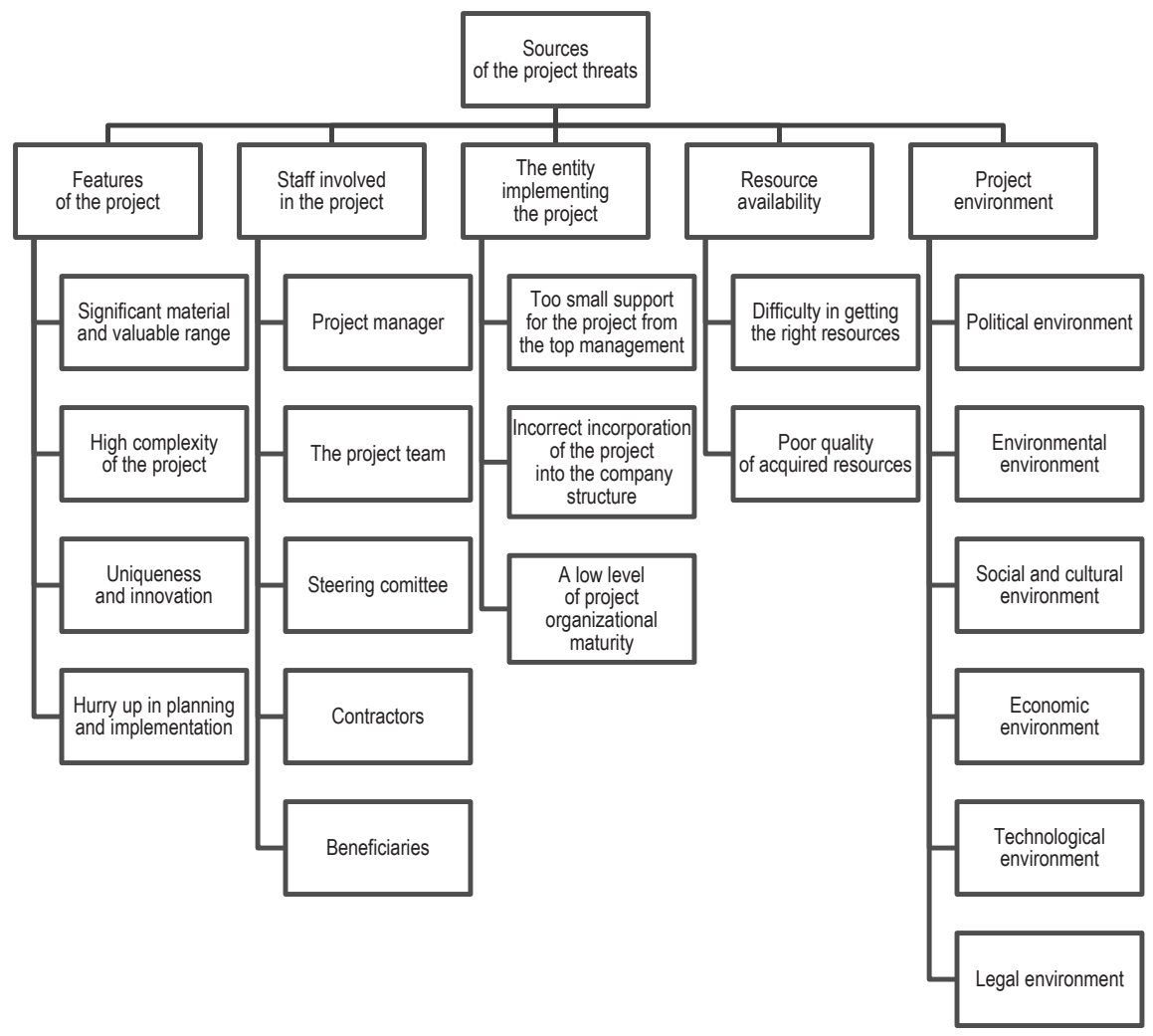

Figure 2 Sources of the project threats

Source: Marcinek K. (2000). Ryzyko projektów inwestycyjnych. Katowice: Wydawnictwo Uczelniane AE w Katowicach. 
Anyone who contributes to the process of risk identification in a positive way can participate in it, for example: representatives of stakeholders, financial experts, representatives of beneficiaries. The main result of identification of project risks is the so-called a risk log or risk register, an example of which is given in Figure 2. It is a document that is supplemented and expanded at every stage of risk management.

During the risk identification, it is very important that risks are formulated in a way that allows for further analysis and planning. According to the british risk management standard, three elements should be indicated for each risk (Trocki, 2012, p. 300):

1. Reason - the objective possibility of occurrence of events, example: because the investment was located near the river and on low ground.

2. Risk - an event that may occur with an estimated probability, example: there is a risk that the construction site will be flooded during spring thaw.

3. Effect - the effect of the actual occurrence of the above-mentioned damage, that may have a positive or negative impact on the objectives of the project, example: what will affect the suspension of work for three weeks.

Only a correct and comprehensive description of the risks gives the opportunity to continue the risk management process in the project. That is why the risk identification is a key stage in the risk management process.

\section{Method}

The research were conducted using the CAWI method (Computer-Assisted Web Interview) among the one hundred and eighty six small and medium enterprises in Western Pomerania. Entrepreneurs were asked three questions closed. Answers to the questions allow to point out are enterprises are making an identification of risk before their projects, and what type of risks they identify. In the research took part small and medium enterprises that implemented project in last three years. Most of the enterprises (78\%) realized project that were financing from UE budget.

\section{Results}

Supplementing the theoretical considerations on risk identification is the presentation of the results of an online survey carried out in the period from August to December 2017 on a sample of one hundred and eighty six small and medium enterprises that implemented the project in the last three years.

Among the objectives of the study, it was indicated to answer the following questions:

1. Did You identify risks before the project was implemented?

2. Which risks did you encounter during the implementation of the project?

3. Did the risks identified before and encountered in the course coincide?

On the first question, concerning the risk identification before the implementation of the project, all responders answered that they identify the risks. None of the study subjects did not reply that its project is risk-free.

On the second question about the risks that encountered during the project, the following answers where get:

- additional costs not included in the project budget (36\%),

- ineligible expenditure (27\%),

- problems with the contact with the supplier or contractor (21\%), 
- errors in the documentation (18\%),

- problems with the financial liquidity of the project $(10 \%)$,

- difficulties in achieving the assumed indicators (10\%),

- errors in accounting records (3\%),

- large fluctuations in exchange rates $(2 \%)$,

- other (2\%).

Most of the entrepreneurs admitted that they didn't include all costs that the project needed, and that they had problems with ineligible expenditure. Such a large share of these two answers certainly resulted from the specificity of the implemented projects, which were in a large percentage projects implemented under the EU programs.

The most answers on the last question, were that the risks coincide. $64 \%$ of the responders answers that they identify the risks that encountered and even more, that didn't. The rest of the responders admitted that they didn't identify all the risk that encountered. The reason why so many of the surveyed entrepreneurs did not identify the risks that encountered was most likely the result of too little importance attached to the risk identification.

The research results show that the risk identification is needed and that project risk managers are using it. It also shows that it is still necessary to emphasize the importance of the risk identification, thanks to which that stage of the project risk management will be more effective and thereby the right strategies to deal with it will be used.

\section{Limitations}

The survey was conducted among companies in Western Pomerania, so the test results may or may not necessarily represent the views of entrepreneurs throughout the country.

\section{Conclusions}

Nowadays, the need to manage risk is noticeable not only in the industry in which the core business is implemented through projects (such as construction, IT, R \& D), but also among other entities, that thanks to the projects are able to get additional funds for the development of their business.

Therefore, in order for the risk management process to fulfill its role, it is necessary for the project managers and unit managers to understand its relevance to the project's objectives and the potential benefits that can be obtained after its effective implementation into the project.

The article presents the results of the research on risk identification in the risk management process in various enterprises operating in the Western Pomerania. Interesting from the point of view of theoretical and practical considerations, it may be a further examination of the risk catalog, which are analyzed by entrepreneurs in their activities.

\section{References}

Bednarczyk, T.H. (2000). Instrumenty wspierania eksportu. Kredyty i ubezpieczenia. Warszawa: Wydawnictwo Naukowe PWN. European Commission (2004). Project Cycle Management Guidelines. Brussels.

Hall, D.C. (2002). What is "Risk". Risk Management Working group INCOSE.

ISO IES Guide 73:2002. Risk Management - Vocabulary - Guidelines for Use in Standards.

Kaczmarek, T.T., Zarzycki, M. (2005). Poradnik eksportera, Bydgoszcz-Warszawa: Oficyna Wydawnicza Branta. 
Marcinek, K. (2000). Ryzyko projektów inwestycyjnych. Katowice: Wydawnictwo Uczelniane AE w Katowicach.

PMI (2013). A Guide to the Project Management Body of Knowledge. Pennsylvania: PMBOK@.

Roszkowski, H. (2014). Ryzyko w projekcie. In: M. Wirkus, H. Roszkowski, E. Dostatni, W. Gierulski. Zarządzanie projektem. Warszawa: PWE.

Rzempała, J., Pieńkos, M., Leśniowski, T. (2015). Zarządzanie projektem badawczym. Kraków: Oficyna Drukarska - Jacek Chmielewski.

Skorupka, D., Kuchta, D., Górski, M. (2012). Zarządzanie ryzykiem w projekcie. Wrocław: Wyższa Szkoła Oficerska Wojsk Lądowych im. T. Kościuszki.

Space Project Management (2000). Risk Assessment, ESA/ESTEC,ECSS standard ECSS-M-00-03A.

Szczepaniak, W. (2013). Zarządzanie ryzykiem w projekcie współfinansowanym z Unii Europejskiej w szkole wyższej. Szczecin: Wydawnictwo Naukowe Uniwersytetu Szczecińskiego.

Tkaczyński, J.W., Świstak, M., Sztorc, E. (2011). Projekty europejskie. Praktyczne aspekty pozyskiwania i rozliczania dotacji unijnych. Warszawa: C.H. Beck.

Trocki, M. (red.) (2012). Nowoczesne zarządzanie projektami. Warszawa: PWE.

Wyrozębski, P. (2014). Zarządzanie wiedzą projektową. Warszawa: Difin.

Wysocki, R.K. (2013). Efektywne zarządzanie projektami. Tradycyjne, zwinne, ekstremalne. Gliwice: Helion.

Yellman, T.W. (2000). Three Facets of Risk. Proceedings 2000 World Aviation Conference.

Zaskórski, P., Woźniak, J., Szwarc, K., Tomaszewski, Ł. (2013). Zarządzanie projektami w ujęciu systemowym. Warszawa: Wojskowa Akademia Techniczna.

Cite this article aS: Soroka-Potrzebna, H. (2018). Risk identification as a basic stage of the project risk management. European Journal of Service Management, 3 (27/1), 277-283. DOI: 10.18276/ejsm.2018.27/1-35. 